\title{
Adoption of SMS and Web Based System to Measure Usability and Effectiveness of Text Alert System as Broadcast Communication for Managing and Disseminating Information
}

\author{
Suriana Ismail and Mohd Nizam Husen
}

\begin{abstract}
Nowadays mobile communication is a necessity as one of the ways of acquiring information. All level of users, including higher education students have a mobile phone as one of their communication device choice. This paper explores the adoption of web based SMS system to measure the usability and effectiveness of this broadcast communication option in disseminating information among students and lecturers. Prototype was developed by adopting iterative software development process- RUP. We examine its usability and effectiveness through sets of questionnaire. Result shows that the propose prototype can be an option for managing and disseminating information.
\end{abstract}

Index Terms-SMS, web based application, mobile phone.

\section{INTRODUCTION}

Short Message Service or commonly used term, SMS is a social technology and has become a popular communication utility among us and especially to the students. Regardless level of user, primary, secondary, and high school or university students, SMS seemed an obvious way for them to be in contact with others.

Today, of all the vast range of alternatives, SMS is increasingly becoming the first choice for reaching audiences (single to single or single to multiple communications - also known as broadcast communication).

The first part of this article describes the problems faced by the students. Next, the research objectives and scope of the project described in this paper are outlined. Later, method to achieve all objectives and the findings are also discussed. Finally, a conclusion part is presented.

\section{Problem Statement}

Currently in Universiti Kuala Lumpur (UniKL), Malaysia Institute of Information Technology (MIIT), method of informing latest information or message between student to student or lecturer such as changes of location and time of class, arrangement of special meeting to name a few are done by posting a notice via notice board, one-to-one text message or from verbal communication. These resulted in late in receiving the information and worst case lost of information. A preliminary study are done using questionnaire and results

Manuscript received July 15, 2012; revised September 12, 2012.

The authors are with the Universiti Kuala Lumpur - Malaysian Institute of Information Technology, Kuala Lumpur, Malaysia (e-mail: suriana@miit.unikl.edu.my, mnizam@miit.unikl.edu.my). shown that there is a need in improving the process of disseminating information.

Below is the current process utilizing manual SMS that helps the lecturer and student escalate information or updates on any event. There will be some delay in receiving the information, resulted problem for the student and lecturer group involved.

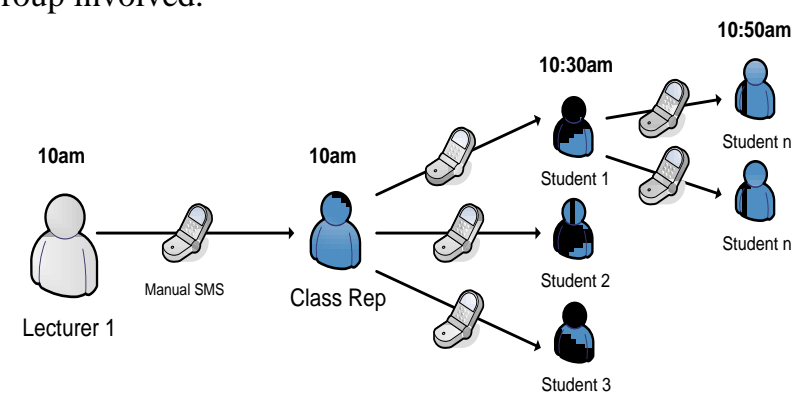

Fig. 1. Current process of disseminating information.

As to overcome this delay in receiving the information, below is the improved process to reduce delay in receiving information. The intended group shall received update of information at the same time.

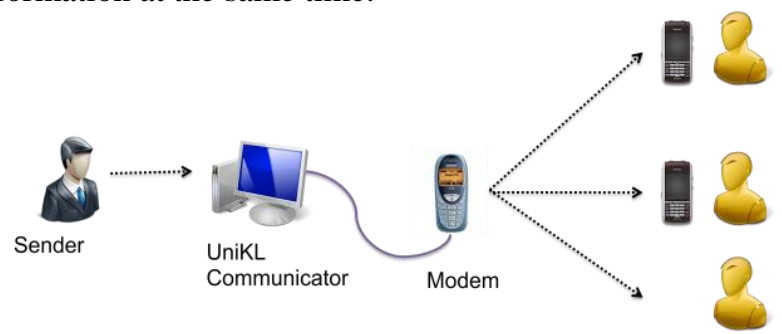

Fig. 2. Improved process of disseminating information using UniNK comm prototype.

\section{A. Objective of Study}

The main objective of this study is to explore the concept of online system as an alternative way to lodge and monitor complaints.

To accomplish this, the following sub objectives are achieved first:

- To develop the requirement model of UniKL CommText Alert System using Unified Modeling Language $(U M L)$ related diagrams.

- To develop the UniKL Comm- Text Alert System application by utilizing web-based portal and Short Messaging Services (SMS).

\section{B. Scope of Study}

In developing UniKL Comm- Text Alert System, the studies done are limited to the MIIT, UniKL city campus only. 


\section{LITERATURE REVIEW}

\section{A. History of SMS Technology}

Before Short Message Service or SMS existence, Global System for Mobile communication or better known as GSM was originally developed to provide a communication technology for Europe. It enables same subscriber units to communicate throughout the continent. GSM first appeared in 1990 in Europe which embedded the essential intelligent functions for the support of personal mobility, especially with regards to user identification and authentication, and for the localization and administration of mobile users [1]. European networks began development of a digital standard (GSM) in 1991. Phase 2 of the standard, release in 1993, defined data bearing services over GSM and SMS was a part of this standard [2][3].

\section{B. SMS Limitation}

As the system does not rely upon fixed line as a land based telephone system does, the amount of information that can be sent at one time is limited in term of size. For example, sending SMS using English characters, the maximum character is limited to 160 only. Unlike sending SMS using Unicode characters such as Chinese or Japanese, it is limited to only 70 characters.

\section{Target User}

SMS was the triumph of the user, every generation need a technology that can be adopted as a mean of communication, and the text generation took up SMS. According to a survey done by Nielson Co. depicted in Fig. 3 below, focused on the comparison of age group communicate using phone call verses SMS, it is found that there are two group; age 13-17 and age 18-24, maximizing the usage of SMS as compared to other group. This creates an opportunity to adopt the SMS technology to the advantage of this group of user [4].

\begin{tabular}{|l|l|l|}
\hline Age Group & $\begin{array}{c}\text { Average Number of } \\
\text { Monthly Calls* }\end{array}$ & $\begin{array}{c}\text { Average Number of } \\
\text { Monthly Text Messages* }\end{array}$ \\
\hline All Subscribers & 204 & 357 \\
\hline Ages 12 \& Under & 137 & 428 \\
\hline Ages 13-17 & 231 & 1,742 \\
\hline Ages 18-24 & 265 & 790 \\
\hline Ages 25-34 & 239 & 331 \\
\hline Ages 35-44 & 223 & 236 \\
\hline Ages 45-54 & 193 & 128 \\
\hline Ages 55-64 & 145 & 38 \\
\hline Ages 65+ & 99 & 14 \\
\hline
\end{tabular}

Fig. 3. Neilsen co survey depicted age group and its usage.

\section{Methodology}

The data and fact-findings were done through questionnaires, observation, structured interviews, and literature review. To investigate the first objective (developing the requirement model), object-oriented approach (with Unified Modeling Language (UML) notations) are used. This approach is particularly concerned with the specification of the attributes types, how the operations function, and how objects are linked to others. For the second objective, data was collected using questionnaires, test document and interview.

\section{E. Questionnaire}

Two set of questionnaire was developed (before and after). The first set of questionnaire consists of two parts, namely:

- Text Alert System to improve information dissemination

- Web based and SMS Technology usage

In the part under "Text Alert System to improve information dissemination", attempts were made to gather data on the respondents' previous record of receiving latest information. It also gathers information whether the respondents' is aware and responding to the message relies. This information would give a general feel of the respondents' background responding to the questionnaire. The second part of the questionnaire is on web based and SMS technology usage, dealt with the respondent's view and experience using the current technology.

\section{F. Observation and Interview}

A series of observation and structured interviews session with the students and lecturer are done. The interview intended to capture the problem faced by the university, the current system used and to depict the text alert system from the organization perspective. The following is the outcomes from the observation and interview:

- Missing of posted information on notice board.

- Single recipient, such as class representative- did not reach others.

- Delay in receiving information.

\section{DeVelopment of UniKL COMM- TeXt AleRt System}

In developing the prototype of UniKL Comm-Text Alert System, Rational Unified Process (RUP) was adopted as its initial software engineering process. The Software Development Life Cycle (SDLC) based on Rational Unified Process (RUP) is followed. The RUP is an iterative software development process framework created by the Rational Software Corporation, a division of IBM since 2003 [5].

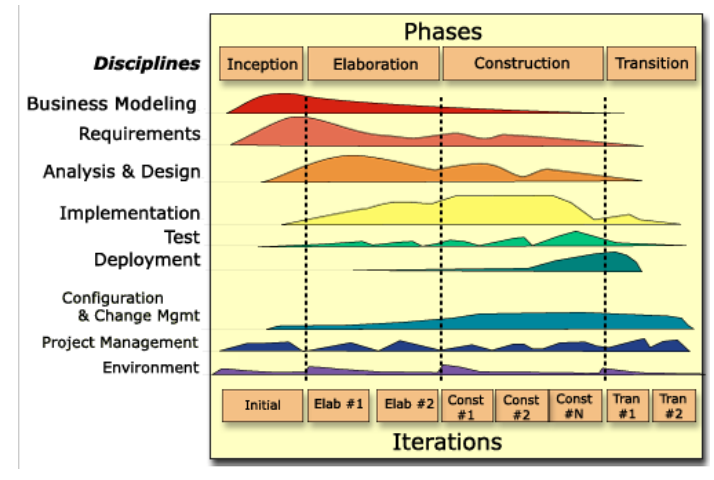

Fig. 4. IBM rational unified process, 2003.

\section{A. Phase 1 and 2: Inception and Elaboration}

The first two phases of Inception and Elaboration are mainly to gather the actual requirements for the prototype to be develop. The requirements are gathered using the Unified Modeling Language (UML). The basic architecture of the system shown below is derived from the requirements gathered earlier. 


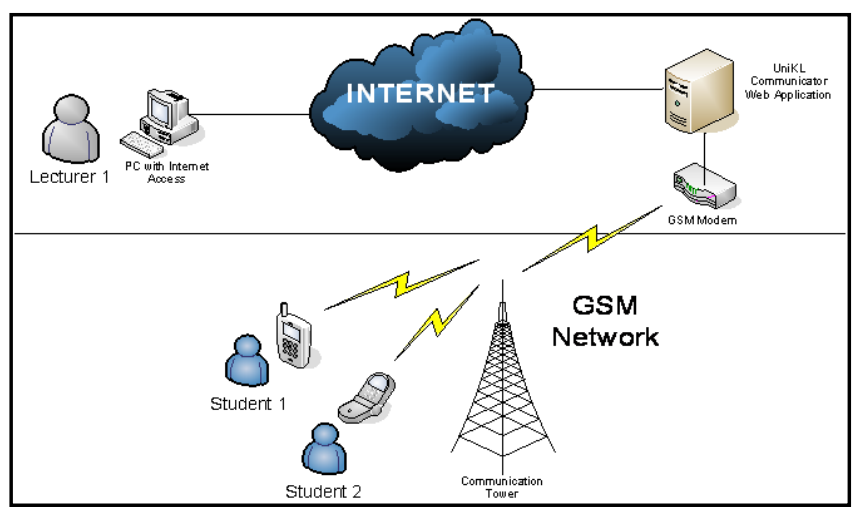

Fig. 5. Basic architecture of the text alert system prototype.

The system particularly supported five (5) main user groups, (Student/Lecturer/Staff/Head Section/Admin) whereby each of them has their own task and limitation of area of coverage.

\section{B. Phase 3: Construction}

The development of the prototype is based on the design from the requirement model architecture which was constructed using the object-oriented design tool, Rational Rose Enterprise Edition. The prototype that was developed in this study used ASP.NET framework with C\# programming language as its core development language and MS SQL as its main storage.

Microsoft.NET C\# as the development tool to develop the SMS prototype, an API of Microsoft Research India (MSRI) SMS Server Agent developed by Microsoft India was used. Developed in C\#, it supports integration between any applications written in .NET technologies with any cell phones running on Windows Mobile operating system.

\section{Phase 4: Transition}

During the testing phase, actual users have evaluated and tested the prototype developed. The user evaluated the prototype using the prepared test cases document. The document practically expressed the testing strategy whereby it include the various test cases, testing methodologies, testing environment, and also the software/hardware tools that been used.

Two (2) types of test are performed:

- Internal Testing (Functional Testing) and

- External testing(Usability Testing)

\section{RESUlt AND DisCUSSION}

The functionality testing is done internally before the prototype been put to external testing. All features tested for each user, Admin, Student, Head Section, Lecturer have passed all functionality test based on the test plan developed. Based on functionality test result, the prototype proved to be functioned as it requirement captured during the initial phase of Inception. External testing was conducted to the same group of users. This usability test intended to get the overall user perception on the prototype developed. Result of the usability test is depicted in the Table I below.

TABLE I: USABILITY RESULt DISTRIBUTION FOR TESTED SAMPLE

\begin{tabular}{|lll|}
\multicolumn{1}{c}{$\begin{array}{c}\text { Overall Perceived } \\
\text { Usefulness }\end{array}$} & $\begin{array}{l}\text { Total } \\
(\mathbf{N}=\mathbf{5 0})\end{array}$ & Percentage \\
\hline Agree & 37 & $74 \%$ \\
\hline Disagree & 13 & $26 \%$ \\
\hline Total & 50 & $100 \%$ \\
\hline
\end{tabular}

Based on the result from the questionnaire given, $74 \%$ of the respondents' agree that UniKL Comm-Text Alert System found easy to use and understand. The following are result for the efficiency of disseminating information.

TABLE II: EFFICIENCY RESUlt DistRIBUTION OF TESTED SAMPLE

\begin{tabular}{|lll|}
$\begin{array}{c}\text { Overall Perceived } \\
\text { Efficiency }\end{array}$ & Total $(\mathbf{N}=50)$ & Percentage \\
\hline Efficient & 41 & $82 \%$ \\
\hline Not Efficient & 9 & $18 \%$ \\
\hline Total & 30 & $100 \%$ \\
\hline
\end{tabular}

Based on the result, it is found that $82 \%$ of respondent agree the prototype is efficient in term of disseminating information. The $18 \%$ of inefficient is due to the recipients' mobile phone is turned off or on silent mode. By providing an alternative way of handling and disseminating information, the services provided would be more efficient because reaches all target recipient not only one representative. Thus this would help better organizing in term of handling and managing class, in particular or a simple event.

\section{CONCLUSION}

Overall, the main objective of this study which was to capture the actual requirements and to develop web based SMS system had been achieved. Findings suggest that this UniKl Comm-Text Alert System developed had a positive effect on providing an effective way to handle and manage class or event. However, this research is limited to only one sample from Universiti Kuala Lumpur-MIIT. Therefore, findings of the study were limited on this sample only.

\section{ACKNOWLEDGEMENTS}

S.Ismail thanks Universiti Kuala Lumpur, as the Short Term Research Grant (STRG) sponsor for this project. Special thanks to research assistants: Khalil Akashah Julaihi; also to all students and individuals who had participated during the survey and testing process.

\section{REFERENCES}

[1] W. Stalling, Wireless Communications and Networks, $2^{\text {nd }}$ ed. United States of America. Pearson Prentice Hall. 2004.

[2] S. Baron, A. Patterson, and K. Harris, Beyond Technology Acceptance: Understanding Consumer Practice, International.

[3] SMS Integration. (2011). [Online]. Available:
. http://www.sms-integration.com/. 20 Jan 2011.

[4] Neilsen Co Survey. (2011). [Online]. Available: http://blog.nielsen.com/nielsenwire/online_mobile/in-us-text messaging-tops-mobile-phone-calling/, 24th September 2011

[5] IBM Rational Unified Process. [Online]. Available: http://en.wikipedia.orf/wiki/IBM_Rational_Unified_Process, 23rd June 2008. 